CATALAN REVIEW

Catalan Review

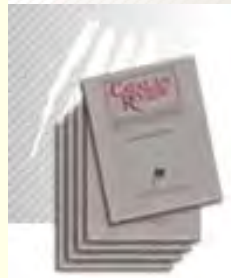

You are accessing the Digital Archive of the Catalan Review Journal.

By accessing and/or using this Digital Archive, you accept and agree to abide by the Terms and Conditions of Use available at http://www.nacs-

catalanstudies.org/catalan_review.html

Catalan Review is the premier international scholarly journal devoted to all aspects of Catalan culture. By Catalan culture is understood all manifestations of intellectual and artistic life produced in the Catalan language or in the geographical areas where Catalan is spoken. Catalan Review has been in publication since 1986 .
NORTH

AMERICAN

CATALAN

SOCIETY
Esteu accedint a l'Arxiu Digital del Catalan Review

A l' accedir i / o utilitzar aquest Arxiu Digital, vostè accepta i es compromet a complir els termes i condicions d'ús disponibles a http://www.nacs-

catalanstudies.org/catalan_review.html

Catalan Review és la primera revista internacional dedicada a tots els aspectes de la cultura catalana. Per la cultura catalana s'entén totes les manifestacions de la vida intel lectual i artística produïda en llengua catalana o en les zones geogràfiques on es parla català. Catalan Review es publica des de 1986.

\title{
A Thought or Two About J. V. Foix M. L. Rosenthal
}

Catalan Review, Vol. I, number 1, (1986), p. 225-236 


\title{
A THOUGHT OR TWO ABOUT J. V. FOIX
}

\author{
M. L. ROSENTHAL
}

A poet of this century; a "modern" who (like the others of his somewhat lonely kind) reaches toward an idealized lost past and lost world of myth about which, nevertheless, he has no illusions; a lyricist of the intractable; an ultra-realist whose intensity needs fantasy and buffoonery to make room for itself; hard, provincial, a bit reactionary, beautifully humane; absolutely alienated; absolutely at home.

The usual contradictions that a marvelous poet resolves by taking them all to his bosom: i.e, into his float of language, rhythms, and silences. It's all there in the very first stanza of one of his early sonnets:

Sol, i de dol, i amb vetusta gonella, Em veig sovint per fosques solituds, En prats ignots i munts de llicorella I gorgs pregons que m'aturen, astuts.

(Alone, in mourning, wearing an archaic black gown, I stray often into dark solitudes, Uncharted plains where high slate-mounds surround $\mathrm{Me}$, and everywhere I'm blocked by ocean-deep whirlpools. $)^{1}$

The lines are at once ravishing and loaded with stop-sounds, the imagery boisterously copious yet projecting frustration at every turn. The second line is Romantic, positively "Byronic" in its haughty, unbroken gloom. Still, there is a shade of

${ }^{1}$ The translations in brackets are my own slightly free adaptations. 
self-parody in the stage directions, as it were, of the first line and the proliferation of images of balked confusion piled up so quickly in the two closing lines (the stanza is hardly comic, but it would need just one more push to match the hilarious exaggeration accompanying the truly terror filled wastelandpassage in "The Hunting of the Snark"). The internal rhymes and half-rhymes and highly functional alliteration (to which all true poets are addicted and whose particular conformation is the individual poet's clearest fingerprint) indelibly trace the dominant currents of feeling.

And on the other hand (actually, two hands aren't enough for all the oppositions and minor calibrations between extrems in Foix!), the twentieth century and its machinery are happily cherished by this poet at times. The stanza just quoted presents a figure better suited, in his "vetusta gonella", for a past age than for this one. But another early sonnet gives us quite a different picture:

De matí em plau, amb ferries tenalles

I claus de tub, cercar la peça llosca

A l'embragat, o al coixinet que embosca

L'eix, i engegar per l'asfalt sense falles.

I enfilar colls, seguir per valls ombroses,

Vèncer, rabent, els guals. $\mathrm{O}$ món novell!

(It pleases me, mornings, to pick up my pliers and other tools And get to work and tighten some snug-fitting pin

So the gear will mesh just right, or adjust a bushing that cushions An axle, and then purr out with smooth power over the asphalt.

And snake up and down mountain-passes, towards valleys in shadow, And ford streams in a furious rush: Ah, a new world!) 
These lines are sandwiched between an opening stanza drenched in antiquarian nostalgia and an ending that combines detached, eclectic aestheticism with an air of breathlessly innocent excitement about everything (both very "modern", - no?) The ending:

Em plau, també, l'ombra suau d'un tell,

L'antic museu, les madones borroses, I el pintar extrem d'avui! Càndid rampell:

M'exalta el nou i m'enamora el vell.

(Also, these things are pleasing: a linden's gentle shade,

A museum of antiquities, madonnas turning dark and fading, And the far-out stuff of our painters nowadays! I'm a child:

Everything new thrills and exalts me, and I'm mad for everything old.)

Closer still to the psyche of our own century is the pressure in Foix to uncover some secret, saving revelation the very thought of which sends joy flashing through his verse - while, at the same time, an ultimate disbelief makes every such foray a possible source of desolation after all. In the sonnet from which I first quoted ("Sol, i de dol, ..."), a powerful, willful act of imagination imposes on the baffling world a landscape closer to the heart's desire: "el paisatge De fa mil anys" (the landscape of a thousand years ago). What a liberation - to recover the transcendent pre-modern Eden-like state of existence where alienation was inconceivable! The warm thought follows that this triumph is God's loving trap for the speaker ("el parany Per heure'm tot"): a sweet paradox Gerard Manley Hopkins would have loved. But wait - at the 
poem's last moment comes the counter-thought that it is perhaps no triumph but the Devil's trick ("del diable engany") to checkmate both the speaker and God. The knot of unclarity at the heart of the most intense sense of transcendence and delight is a frustration Foix seems to exult in.

That is, a natural exuberance of discovery charges his spirit even when what's discovered is tragic. Thus, the sonnet "Jo tem la nit, però la nit m'emporta ..." (I'm afraid at night, yet meanwhile night carries me away) begins in terror and one can't say it ends any other way. But the striking energy and dynamics with which it rings its changes somehow give an illusion of triumph. The opening lines are followed by images of incompetent offstage music ("la cobla se sent, confosa"), then of utter loneliness and a ruinous landscape, and then suddenly of a moment of transforming vision: "Però jo hi veig una selva frondosa, I en erm desert imagín una porta" (But I peer deep and spy a lush woods in their midst, And imagine a doorway in the wasteland).

What follows "should" be a paradisal evocation of some sort - and what we get, for the moment, is a child's version of delight. Suddenly "la fosca nit m'aparenta pissarra" (the pitchblack night seems to me a huge blackboard), on which one can draw anything one wishes: funny faces, pictures of the dream world we all desire, whatever the innocent imagination can create. But this, it turns out, is only a momentary respite. After it comes the stark realization of the ultimate impersonality of the cosmos. Foix ends this remarkable sonnet, whose dynamic scope is that of a far longer poem of epic density, in a welter of rival tonalities - a tremor of fear, a thrill of cold, pure understanding of the distance of "wisdom" from human needs, a strange half-note demeaning that thrill of awareness, and a brutal summing-up of our condition: 
Me'n meravell, i tem $\longrightarrow$ oh nit que afines Astres i seny! - La mar omples de vestes, I una veu diu: "Plou sang a les codines".

(I gape, I'm afraid —oh night that isolates naked and pure Stars and wisdom! You fill the whole sea with cast-off clothes, And I hear a voice saying: "Blood's raining into the cisterns".)

Here please let me digress on the point made in the footnote to my first bit of translation: that I am offering slightly free adaptations rather than strictly literal renderings. Not that I depart deliberately from Foix's lines; but I do want, rather emphatically, to suggest his evocative resonances as best I can in English. Thus "cisterns" is not quite the same as catchments, which might render "codines" more precisely. But in context the closing image has nothing to do with rural sanitary engineering and everything to do with gross fatality. Catchments is too blandly technical, for considerations of sound and immediacy of evocation must take precedence. For this reason, too, I have rendered "afines" as "isolates naked and pure" and "vestes" as "cast-off clothes". Ordinarily a poet strives to make a piece of translation as loyal to the original as possible: that is, as loyal as natural, idiomatic phrasing and one's talent will permit. Adaptation is inevitable (I should add here that in translating several of Foix's poems, partly to enter their world of feeling and artistic discipline, I have freely exploited the work of David H. Rosenthal as my crib. His translations are of course conditioned by the rigors of sensitively conscientious scholarship. As an accomplished poet making a whole body of Catalan writing available in translation for the first time, his responsibility has been far greater than that of someone just trying, like me, to tune in on Foix with what empathy he can muster). 
To return to the dynamics in Foix's poetry, his place as a master of this crucial element in poetic structuring seems selfevident. We have seen its workings in "Jo tem la nit ..." with its narrative surface that for a short time only conceals its basically lyrical method - i.e., its surprisingly abrupt associative juxtapositions. We find this even more strikingly in the brief, beautiful "Es feia fosc i miràvem l'estesa de pells a cal baster" (It Was Growing Dark and We Stared at the Hides Scattered about the Saddler's House), dated April 1928. Here too the poem presents itself as a sequence of events but unfolds into a collage or, more actively, a montage of images (Eisenstein's old film Romance Sentimentale come to mind as I write this):

Ja els fumerols acotxen els jardins;

Les rels, per terra i murs, s'ajoquen al misteri.

Tots dos, efigies de cuir abandonades

A la fosca arenella de la nit,

Cedim, fraterns, a l'hora fraudulosa.

Abrivades, les egües, afolcades,

Nades a l'ombra i a l'ombra nodrides,

Assolen els poblats.

Damunt la pell d'elefant del cel

Els astres obren llurs camins airosos.

(Already vapors enfold the gardens;

Roots draw back into mystery, in earth and in walls-

All the mock skins of things, now forgotten,

Lost in the deep sandpits of the night,

Friendly, we cede them to the deceitful hour.

Aroused and nervous, herds of mares

Born in shadow and nourished by shadow

Reach the tiny hamlets.

High above the elephant pelt of the sky

The stars open out their airy pathways.) 
This poem exists in a kind of nervous ecstasy of balances, between "Ja els fumerols acotxen els jardins" (the changing scene down below on earth) and "Els astres obren llurs camins airosos" (the vast expansion of perspective far up above the clouds). A succession of hardly related metaphors, each comprising three lines at most, make their momentary appearances between these parallel yet opposite opening and closing images. Although they seem independent of one another, the pressure of association among the several metaphors is nevertheless compelling; they accompany the sense, at once enchanted and foreboding, of the ever-encroaching night. And also, they are elements of a proliferating imagery of skins (or coverings, or contexts, or concealments, or even things merely connected with leather). Everything is an illusion or pelt of something else - so much so that perhaps the "saddler's house" of the title is simply the wide world with its endless nexus of secrets within secrets: the only "revelation" we're ever likely to get, though less harshly thrust at us here than in "Jo tem la nit, ..." One by one, we are told, we "cede" the familiar appearances of things, themselves deceptive "efígies de cuir abandonades" (mock skins of things, now forgotten - or more literally: leather effigies, abandoned), in exchange for other mock appearances. The deceitful hour ("l'hora fraudulosa") of changing forms finds us friendly and receptive ("fraterns") to its trickery. And no wonder, given the lovely images of the darkening world as herds of mares galloping toward all the tiny hamlets, and of the clear open pathways of starlight above the "elephant pelt of the sky", that end the poem.

The charm of these images may make us forget, for a moment, that they are figments of a "deceitful hour" of a type to which the human mind is all too amenable. It is, indeed, a kind of conspiracy between ever-changing outward forms in 
nature and our subjective imaginations. The negative notes planted along the way in the poem are manifold despite the exquisite play of sound, rhythm, and visual impressions. The assonance, consonance, and internal rhymes alone (to say nothing of the gardens disappearing in shrouds of mist, the shadow-mares, or the gracious stars) could seduce an angel into losing sight of the implied malaise and insecurity.

Among Foix's most famous poems, I am told, is the one that was brought to my attention first:

VAIG ARRIBAR EN AQUELL POBLE, TOTHOM ME SALUDAVA I JO NO CONEIXIA NINGÚ; QUAN ANAVA A LLEGIR ELS MEUS VERSOS, EL DIMONI, AMAGAT DARRERE UN ARBRE, EM VA CRIDAR, SARCÀSTIC, I EM VA OMPLIR LES MANS DE RETALLS DE DIARIS

(I GO TO THAT TOWN, THEY ALL GREETED ME, AND I DIDN'T RECOGNIZE A SOUL; WHEN I STARTED TO READ MY POEMS, THE DEVIL, LURKING IN BACK OF A TREE, CALLED OUT TO ME, JEERING, AND PILED CLIPPINGS INTO MY HANDS)

Titles like this one are an attractive mannerism of Foix's. They are little prose-poems in themselves, with an air of serious whimsy (read "surrealism" instead, if you wish); and they prepare us for the special bearing of the poem to come. In fact, they get the poem itself under way, like Japanese paper flowers that expand in water. In this instance we soon get to see that the whimsy is actually a bold psychological realism, that the lack of communication with the people in the town is grimly a sign of the times and of the crisis of poetry, and that the insolent presence of the Devil, at first sarcastically calling out and then confidently expectant, is a genuine pressure of evil and torment. The poem is dated September 1942, when Franco 
was at the height of his power. Repression and cruelty, together with the other accoutrements of Spanish fascism, were in the saddle, and public conversation in Catalan - let alone publication - was forbidden.

None of this is stated in the poem explicitly, and so it would be possible to argue that the "pool of blood ... shining" ("Clareja un toll de sang") in the third stanza, the suggestions of the Church's association with state power in the first and sixth stanzas - "flors al campanar" (flowers on the steeple) and "El bisbe em condecora" (The bishop decorates me - doubtless by pinning a cross) - have no necessary political significance. Similarly, one could not necessarily prove that the "I" of the poem re-embodies — with his "naked foot" associated with a "pool of blood", his (carpenter's?) apron, and his confrontations with the Devil - Jesus in various phases of his life and his Crucifixion, although there are many such implications in the poem. The fusion of persecuted Jesus, the poète maudit, and the ordinary person abandoned to a heartlessly indifferent political order supported by the Church and given to propaganda without content is suggested everywhere - and everywhere ambiguously. Under the sway of this order, the composite protagonist is unsure of his own identity and mission and cannot make contact. The opening stanzas may illustrate:

Com se diu aquest poble

Amb flors al campanar

I un riu amb arbres foscos?

On he deixat les claus...

Tothom me diu: - Bon dia!

Jo vaig mig despullat;

N'hi ha que s'agenollen,

L'altre em dóna la mà. 
- Com me dic?, els pregunto.

Em miro el peu descalç;

A l'ombra d'una bóta

Clareja un toll de sang.

(What's the name of this place

With flowers all over the steeple

And dark trees by the river?

Now where did I put my keys...

Everyone greets me: "Good morning!"

I'm walking around in tatters;

Some of them genuflect,

Another gives me his hand.

"What's my name?" I beg them.

I stare at my naked foot;

In the shadow of a barrel

A pool of blood is shining.)

The poem sinks further and further into desolation, interspersed with bits of wry pathos - touches of innocence again distantly suggesting the Christ figure - and of straightforward satire. Near the end the speaker asserts that he's headed for Font Vella: a place-name for many spots in Catalonia, cognate with Fontvieille in Provence. The "meaning" may be literal and therefore not especially pointed; or it may be taken symbolically if we translate it into "Old Wellspring" or "Old Fount" - in which case the suggestion is that he intends to return to his source: Godhead for Jesus, and an older, better world for the poet. But he still has the Devil to confront and resist at the very end. The poem has no "solution", whether political, moral, or existential. Extremely active in detail, it reaches the same bitter edge of unclear perspective - whose character is nevertheless clearly perceived - as the more privately oriented poems referred to earlier on: 
Me'n vaig a la Font Vella:

N'han arrencat els bancs;

Ara veig el diable

Que m'espera al tombant.

(I'm headed for Font Vella:

They've cleared away the benches;

And now I spy the Devil

Waiting for me on the corner.)

Well, somehow it doesn't seem to matter that joy triumphant doesn't reign in Foix, and that a dark bafflement is never quite overcome. The life of poems lies in the way they cope artistically with the pressures informing them. In "Vaig arribar en aquell poble ...", everything in the town the speaker has reached seems set for celebration, and he himself is under the impression he was invited to give a poetry-reading and that the crowds are waiting for him (he is a little like Kafka's hero in The castle). But the whole festive occasion dissolves, the audience just drifts away, and the spots of horror and confusion reveal themselves. The unrhymed quatrains are both alert and terse, and there are no abstractions to interrupt the succession of events, expressions of feeling and sensation, and shifting grammatical formations that accompany the very concrete and colloquial account the poem gives us.

In these few examples of Foix's work I have discussed, we can see something of his authority as a poet of our century, and of the contradictions and the struggle to overcome alienation that color and dominate modern sensibility. A long historical memory and a deep love for the past contend with a helpless skepticism toward all certainties. Every hour is in this sense a "deceitful hour", to which we must yield however much we would have it otherwise. But all this would be irrelevant were 
it not for the rich and witty dance of sound, and the subtie yet vivacious phrasing, that possess and direct our attention. The combined intimacy, dignity, and half-clowning of this poet give him all sorts of affinities with Yeats, despite every difference of personality and literal technique.

M. L. ROSENTHAL SUFFERN, N. Y. 